\title{
Contribution of NEO Modernism Thoughts on Islamic Thoughts in Indonesia
}

\author{
Annai Saburi, Hasan Bakti Nasution, Irwansyah \\ State Islamic University of Sumatera Utara, Indonesia
}

\begin{abstract}
The aim of the study is to find out the contribution of NEO modernism trought on Islamic trough in Indonesia. This result of the study is Islamic Civilization" in this case, especially Nurcholish Madjid, considers that Islamic rationalism, which in the classical Islamic tradition emerged in the Mu'tazilite theology and Al-Kindi to Ibn Rushd's theology, then systematically became the rational theology of Muhammad Abduh. Basically Hellenistic, because that is not an Islamic genuin. Theological thought and Rational philosophy according to Islamic circles This civilization was built from the construction of Greek theories (especially Aristotle), which from an Islamic point of view, is actually quite problematic, because it is too Rational. The weakness of this Islam, according to the circles of 'Islamic Civilization because they lack in providing an equilibrium in religious life, which is practical and direct to the daily appreciation of God.
\end{abstract}

Keywords

contribution of NEQ modernism Islamic

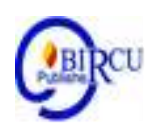

\section{Introduction}

Religion has a function to foster brotherhood especially among internal religious communities. But like the two sides of the religious coin, it has a dual role to play between integrative functions and disintegrative functions in social reality, depending on the context of internal or external relations of religious communities. (Muda et al, 2020)

In Islamic studies, the study of Neo-Modernism is very interesting because this study tries to dialogue between something old and something new, Islam as a religion that encourages to always caring about social problems, teaches human empowerment by respecting human values.

History records that the most spectacular aspect of modernization is the shift of production techniques that rely on the use of animate sources, towards inanimate sources, as summarized in terms of the industrial revolution. In its development the process of changing production techniques is only one aspect of the modernization process.

The process of modernization also hit Indonesia, where Indonesia is a country with a Muslim majority population, of course, to respond to the ideas of modernism in various forms in accordance with their educational and cultural background. However, of course the dynamics and power struggle between conservatism (which has always looked at Islam in the past) and progressivism (who want to reconstruct Islam for the future) is a latent agenda of Muslims throughout history. It is inevitable. Therefore, when the term "renewal" of Islam is put forward, the attitude of Muslims is often doubtful and ambiguous between "agreeing" (because it is a historical necessity and necessity) and "reluctant" (lest it will undermine the authority and authority of religious doctrine).

Regardless of whether or not they agree with the Islamic reform movement, the true color of Islam that has developed in Indonesia has undergone many modifications, deviations, adaptations, and reinterpretations of Islam that developed in the time of the Apostles, the times of friends and also developed in the Middle East. Especially in the past three decades, 
the spirit, direction and style of Indonesian Islamic thought had a very impressive "progress" or "renewal of thought". This development basically talks a lot of things. Among others, the involvement of social sciences that is empirical in translating the message of Islam in analyzing the social situation of the people.

\section{Review of Literature}

\subsection{History of the Emergence of Islamic Thought Ideas in Indonesia}

Today's political approaches to Islam, as recently developed by a new generation of intellectuals and Muslim thought above tend to be inclusive and integrative (2) how they try to realize the socio-political goals of Islam.

Politics is politics that is awakened on the basis of pragmatic and opportunist ideologies. Massive intimidation and mass mobilization accompanied by money politics and imagery are characteristics of mass politics. In mass politics the potential for conflict is also quite high. It is not uncommon for people to become victims. Just because of different clothes, one can brush each other and mutually kill it even more so if the elite he supports loses the election. (Iryadi, 2019)

Since the 1970s, in a phenomenon that was quite phenomenal at that time, the pioneers of the new Islamic intellectualism tried to formulate political aspirations of Islam in a direction that was not subjective and ideological. In line with the unbeatable efforts of the generation of Muslim intellectuals at the time to redefine the social and political objectives of Islam, the agenda of the Islamic group: it is now articulated in a more inclusive and pragmatic style. In this connection, the aspirations of Islamic politics are designed in such a way that they do not have to clash with the people of Indonesia. In turn, this is expected to create a relatively harmonious relationship between Islam and Indonesia.

If the works written by the above figures can be used as an indication, it is clear that the political and political aspirations of Islam today are starting to be synthesized and integrated with the interests and ideals of Indonesian society as a whole. The direction taken demonstrates an ingenious approach to emphasizing the integration of Islam with Indonesia into two important elements which in the socio-political development in Indonesia are often placed in a line of sight.

Viewed from this particular perspective it can be concluded that the ideas of Baldatun Thayyaibatun wa Rabbun Ghafur and Al-Amru bil-Ma'rufi wal-nahyu anil munkar in political Islam in Indonesia today are no longer articulated in the context of ideological and symbolic subjectivism (ie the state Islam and Islamic ideology). Instead these ideas are translated and elaborated into several agendas that relate to the interests of Indonesian society as a whole, covering broader issues such as democratization ${ }^{1}$ of religious and political ${ }^{2}$ tolerance, socio-economic egalitarianism and political emancipation. ${ }^{3}$

${ }^{1}$ See, Just an Example, Nurcholish Madjid. Cita-cita Politik Kita, dalam Bosco Carvallo dan Dasrizal (eds). Aspirasi Umat Islam Indonesia, (Jakarta : Lappenas, 1983), p. 178.

${ }^{2}$ See, For example. M. Dawam Rahardjo, Umat Islam dan Pembaharuan Teologi, dalam Bosco carvallo dan Dasrizal (eds). Ibid.H. 17-132. Lihat Juga artikel Djohan Effendi, Pluralisme Pemahaman dalam Perspektif Teologi Islam, dalam M. Mansyur Amin (ed), p.149-152.

${ }^{3}$ See, For just an example, artikel Adi Sasono, Islam dan Sosialisme Religius, dalam Bosco Carvallo dan Dasriyal (ed). h. 109- 16. Lihat juga artikelnya, Keadilan Sosial Tema Abadi dalam Muntaha Azhari dan Abdul Mumun Saleh (eds), Islam Indonesia Menatap Masa Depan, H. 108- 118. dan artikelnya, usaha pengembangan emanisipasi sosial beberapa catatan, dalam A. Rifa'i Hasan dan Amrullah Achmad (eds).p. 322-335. 
With this approach they believe that the expression of Islamic political goals will no longer be seen as marginal. And more importantly they also believe that such political thought and practice will not be seen as a threat to "national unity", it is because the substance of their socio-political program is objective and integrative in view of the interests of the majority of the Indonesian people. In other words because of the quality of their agendas that include them, the political aspirations of Islam no longer recognize religious or other primordial boundaries.

Thus since the mid-1970s along with the ongoing political restructuring process of the New Order government (1973), which resulted in the limitation of the number of political parties to only three (Golkar PPP and PDI), a new generation of Muslim thinkers decided to articulate the idea of political Islam through a mechanism - broader mechanism. In this case additional channels that are also used are NGOs, mass media, publications of state institutions, and other relevant powers.

Using these institutions to achieve Islamic socio-political goals is a logical step. In fact it also permits the natural consequences of the growth of new intellectualism. Because this generation of thinkers of the new season has already said their willingness to engage in new discourse on political Islam, the use of other possible channels (besides political parties) is largely based on mechanism which has direct affinity with their intellectual social basis. Apart from the political structure of the New Order government, their choice in the arena of various social and political activities was directly affected by their increased exposure to modern education and communication.

Among Muslim thinkers whose main concern is the social transformation Dawam and Adi Sasono are actively involved in various NGO activities. In the 1970s, with research institutions. Education and economic and social information (LP3ES) as their main base, many of the new intellectual figures such as Dawan and Adi Sasono and friends set forth social transformative agendas. ${ }^{4}$ Together with several institutions, especially the Ministry of Religion and important figures directly related to the pesantren, they introduced community development programs through the pesantren. They formed the Institute for Development Studies (LSP), a research institute for development issues that was more oriented towards urban projects and in the 1980s, together with the growing need and interest to develop the quality of pesantren education, together with pesantren leaders who influential as well as graduates of IAIN. They founded the pesantren and community development association (P3M). ${ }^{5}$ All institutions of social transformation are action (or praxis) oriented. All of their social agendas are based on experience. Therefore, emphasis is always given to the practical dimensions of community development programs. They stimulate a number of programs that contain concrete contents towards increasing the socio-economic and political welfare of their target groups, especially those at the grassroots level. Their transformation programs include the development of small-scale industry, animal husbandry, training, and skills. Appropriate technology, health and nutrition, awareness cooperatives and the informal sector.

To channel their ideas which tend to be more intellectual and speculative (although in the long run are expected to have practical consequences) the growing intellectual generation of Muslim thinkers organizes various relevant study groups such as Nurcholish Madjid pioneering the founding of the Paramadina waqf foundation. Likewise, it even preceded the

${ }^{4}$ This is by no means meant to state that LP3ES is an Islamic NGO. However, it is important to be reminded that many of the management are Muslim activists. Politically, as had been predicted by Masyumi and PSI in the early 1950s (for example the idea of a democratic and egalitarian state). For this last statement, see 2. Wilham lidle. "RMS" Tempo, 10 April 1993: p.104.

${ }^{5}$ For an overview of PSM activities. see some of the essays related to him in Naufred Oepenand Walfgaf Karcher (eds), The Impact of Education and Community Development in Indonesia, Jakarta, P3M. 1988. 
establishment of Paramadina ${ }^{6}$, M. Dawam Rahardjo, an institution of religious and philosophical studies (LSAF) ${ }^{7}$

In addition to these new efforts, the supporters of the new Islamic intellectualism also made use of large Islamic organizations such as Muhammadiyah, NU and MUI. ${ }^{8}$ They see great potential in these religious social organizations, both as institutions that can support and articulating interests as well as suitable institutions to fight for their socio-economic and political goals.

There is a main reason behind that assumption. That is, from the perspective of the representation of Islamic interests, these organizations especially Muhammadiyah and NU can be seen as the two most authoritative institutions that symbolize the collective aspirations of Indonesian Muslims. With around sixty million members scattered in rural and urban areas throughout the archipelago there is no doubt that both represent a sizable segment of Indonesian Muslims. ${ }^{9}$

Among the Muslim reformers thought above. Adheres to the substranialist approach to Islamic social doctrines. By emphasizing the substantive side of politics, they reject the formalistic and legalistic objectives of Islamic politics. Therefore, from the beginning they did not aspire to establish an Islamic state. In fact, as discussed earlier based on their understanding of Islamic doctrines and the sociological features of Indonesian society, they oppose the idea of Islam as an ideology of the state. Their main concern is instead centered on the development of a socio-political system that reflects Islamic political values.

Although there is no formal and legal political link between Islam and the state, they fully believe that the form of their countries fully believes that the form of the Indonesian nation state today with Pancasila as an idiological basis is sufficient to accommodate the application of Islamic ${ }^{10}$ Social and Political teachings. In other words, the state at least theoretically provides opportunities and opportunities for the application of Islamic social political idealism.

The fact that these socio-political objectives are fundamentally democratic in nature has not yet been fully implemented or realized, perhaps with a few exceptions during the liberal democratic period of the 1950s, it must be regarded as a joint responsibility of all Indonesian citizens. In line with this point of view, many of the figures of the new generation of Muslim thinkers argue that this particular problem (and many other state issues related to it) should not be understood as an acceptable reason for changing the pattern of the "national unity" of the Indonesian state instead efforts to reestablish democratic principles or to overcome other

${ }^{6}$ Ibid

${ }^{7}$ When it was first established, LSAF was led by M. Dawam's colleagues, Rahardjo who was younger. Later, in the late 1980s, after spending his term as Director of LP3ES he himself was the leader of the LSAF. LSAF mainly organizes regular and open forums to discuss religious and philosophical issues. The institute also publishes the quarterly journal Umm al-Qur'an.

${ }^{8}$ Formed in 1975, the Indonesian Ulema Council (MUI) is an institution supported by the government. This institution is an autonomous body outside government agencies, and is sometimes critical of a number of government policies regarding Islam. However, as is well known, its formation was carried out on the blessing of the New Order government. One of the main functions of the MUI, especially in the first year of its formation, is to foster a more positive relationship between the ulama (religious leaders) and Umara (state leaders)

${ }^{9}$ There are no exact figures that indicate the exact number of members of both Muhammadiyah and NU. The figures quoted here are based solely on claims made by both parties. For evidence on the organization's representation, see Tempo magazine reports, December 2, 1989, and December 15, 1990 See also Abdurrahman Wahid's statement in "The recent NU Grand Meeting in Jakarta as quoted in Tempo in several editions of March 1992 and Panji Masyarakat, 1-10 March 1992.

${ }^{10}$ Look at just an example, artikel Nucholish Madjid, Cita- cita Politik Kita, dalam Bosco Cavpollo dan Dasrizal (eds), p, 1-36, 37-63, and 117-132. 
Indonesian socio-political problems must be made within the framework of the existing state diology contract. ${ }^{11}$

Such a view is based on the general understanding that democratic political arrangements are inclusive and are shared by almost all modern politics, regardless of their religious affiliations. In the Indonesian political context, this point of view is exemplified by the fact that in the early 1950s, such political idealism had become a meeting point for the development of relatively harmonious political relations between Islamic groups (Masjumi) and non-Islamic groups (parties Christian and Catholic socialist parties. ${ }^{12}$

Second, from a goal-oriented perspective, by promoting such social-political objectives and rejecting the idea of an Islamic state or Islamic ideology, the figures of the new generation of intellectualism above have paved the way for ongoing integration into the mainstream of national politics, and therefore, at least as a theoretically, it increases the opportunities and opportunities for its participants to be fully involved in Indonesian political discourse. And that will ultimately make them proportionally represented; both at the parliamentary and executive level (bureaucracy). In other words, from a practical political perspective, the style of these socio-political goals, as some Muslim thinkers imagine, will increase the likelihood for leaders of political Islam activists today to have a say in determining Indonesia's future ${ }^{13}$. Or, as stated by Nurcholish Madjid, the socio-political objectives have the potential to play a role as a possible foundation although it is clearly not the only one for finding a new political balance in which the majority of religious groups in the country can fully participate in national development. ${ }^{14}$

What the new Muslim intellectual group has achieved in the last two decades, both in theoretical and practical terms, has shown that the realization of that ultimate goal is something that may be a political and bureaucratic breakthrough that has been pioneered by Muslim bureaucratic political reform figures, can be read as a strategy It is important to pave the way for the reintegration of political Islam this time which has an integrative and substantive pattern into the country's political discourse. Likewise the activism of Muslim social transformers is designed to discuss relevant social emancipation agendas, which aim to build a civil society that is relatively strong economically and politically. This is what makes it possible for the community to play the role of "participant" rather than merely complementing sufferers in Indonesian political life.

The socio-economic and political emancipation is truly reflected in the ideology and activism of the new generation of Muslim intellectuals above. Although it does not cover the entire spectrum of the aspirations of the Indonesian Islamic community, the publication of the book "The aspirations of Indonesian Muslims textually demonstrates their determination to reject formalistic and legalistic political Islamic objectivism, while reaffirming their commitment to economic and political ${ }^{15}$ democracy through a series of national and group meetings. limited discussion groups, these agendas were then further developed ${ }^{16}$ the

${ }^{11}$ Article Nucholish Madjid, Cita- cita Politik Kita, in Bosco Cavpollo dan Dasrizal (eds), p. 1-25, 37-63, dan 117-132.

${ }^{12}$ See Bahtiar Effendi's Interview with Dawam Rahardjo in Jakarta, August 20, 1991. interview with Nurcholish Madjid in Montreal, 3 Noveber 1991. See also "What do Indonesian Muslims want? Nurcholish Madjid interview with Salim Said, April 22, 1991 in Bahtiar Effendi, Islam and Nepara Transformative Islamic Political Thought and Practice in Indonesia, Jakarta. Paramadina, 1993. p. 198.

${ }^{13}$ Ibid

${ }^{14}$ Ibid, lihat juga Nurcholis Madjid, Islam dan Birokasi, Tempo, 28 Desember 1991, pp. 28-29

${ }^{15}$ This book only contains the thoughts of Nurcolish Madjid. Adi Sasono, M. Dawam Rahardjo, Ahmad Syafii Maarif Hidayat Notoatmodjo, and M. Amin Rais.

${ }^{16}$ In December 1984, several people active in LP3ES (at Dawan Rahardjo), LSP (Adi Sasono), PA (M. Amin Aziz), UIKA (Am. Saefuddin) and MUI (Hasan Basri) organized a national gathering of Muslim scholars. 
establishment of the Indonesian Muslim Intellectual Association (ICMI) in Malang in December 1990, could act as a national forum where Muslim intellectuals and activists could elaborate the above objectives of economic and political democratization into components relevant components.

Compared to the other two intellectual streams, rational Islam and Islamic civilization, perhaps the flow of social transformation has a better advantage in relation to the Muslim community as a whole. That is because the main concern of this flow is how to develop an understanding of the relative autonomy of civil society in relation to the state. With this idea as the background of his movement, it is hoped that social transformation activism is able to lay the foundation for community involvement not only in the nation's national development, but also in the process of policy making.

In practice, the main agenda of this flow covers a variety of practical issues, from nutrition improvement to awareness of the socio-economic and political rights of the community. And because of its orientation that touches the earth, there are no serious objections addressed to the activities of these social transformation figures. Even most of their programs are welcomed with enthusiasm, as seen in the close and mutually beneficial cooperation between them and local leaders, this positive response is a very decisive factor for the success of this social transformation discourse. ${ }^{17}$

This continuing obstacle is exacerbated by the fact that some NGO funding comes from foreign aid. ${ }^{18}$ In the eyes of its activists, this peace relationship is the best way to maintain their relative autonomy in terms of their relations with the state. But in the view of the state, the involvement of foreign funding agencies brings with it several socio-political agendas that may not be fully in line with state policies.

Because of these structural barriers, proponents of the flow of social transformation cannot further articulate their agendas. To a certain degree, their commitment as spokesmen for socially and economically and politically weak community groups must be compromised with the interests of the state. ${ }^{19}$

The sources of support and obstacles above are not permanent. Everything flows according to the changing situation. In this connection, the deciding factor lies in the extent to which the socio-economic and political aspirations of Islam are accommodated by the state.

Within the framework of such an analysis, it is interesting to note that the greatest changes occurred in relation to the obstacles faced by supporters of bureaucratic political reform. The increasing attention of Golkar to the aspirations of Islam, especially since the 1980s has really reduced the traditional suspicion of many Muslims towards this political organization. Especially for this reason, although certain doubts are still felt, some Muslim commitments have become easier to accept the political gait of Golkar and the Muslim activists within it.

Meanwhile they are seeking bureaucratic breakthroughs increasingly accepted by the wider Muslim community segment. The fact that their involvement in the state bureaucracy has provided space and another opportunity for the struggle for Islamic aspirations marked by

This meeting was intended to see the strategic role of Islam in the framework of national development. Issues such as the ethos of development, culture, technology, economy and social politics are discussed as part of a strategy to identify strengths, weaknesses, opportunities and threats. For more information about this, see A. Rifai Hassan and Amrullah Achmad (eds). Op. Cit.

${ }^{17}$ One of the success stories of social transformation is the community development programs implemented in collaboration with a number of pesantren, especially in Java, for a more in-depth look at the relevant essays in M. Dawam Rahardjo (ed). Pesantren World Knowledge: Building from below, Jakarta: P3AI, 1975.

$$
\begin{aligned}
& { }^{18} \text { Ibid } \\
& { }^{19} \text { Ibid }
\end{aligned}
$$


their relative success in the process of Islamization of the bureaucracy, is a strong indication that the struggle for Islam does not necessarily require Islamic social and political institutions.

Mainstream, which has become an obsession with the attention of Islamic thinkers in Indonesia, has entered a space that is truly cultural, theological and philosophical. Reformers often think about how Islam can contribute and become part of Indonesian modernity. The idea of a conducive Islam with chronological social change emerges, this is the beginning that determines the long journey of reformist Islamic thought in Indonesia. Since then, the attention of reformer groups has shifted from political Islam to cultural Islam in the form of cultural thinking. This can be seen about the journey of democracy and its melting groupings of Muhammadiyah and NU political parties. ${ }^{20}$

Their thoughts are actually quite varied according to the subject matter that is their main concern. Even so there is one mainstream that became their obsession, namely to build a modern Islam, which is called Islam, Indonesia, and Modernity. From Nurcholish Madjid, arguably is a symbol of what is an attempt to reflect their thoughts. Of course, how is it translated in a more concrete sense each character has its own interpretation and at the same time has its own social theory, implicit or explicit.

Social theories, especially Critical Theory, always look at the relationship between social theory and political practice. ${ }^{21}$ So in fact behind any of their thoughts in essence contained views about political practice. Thus every Islamic thought is essentially implicit or explicit has a certain political content. The relationship between a reflection on Islam and political practice in order to clarify the spectrum of reformers' thinking.

\section{Discussion}

\subsection{The Contribution of Neo Islamic Modernism Thought in Indonesia}

In a systematic way there are three forms of social thought to Islamic reformers, which are called by using their own terms namely Rational Islam, Civilization Islam and Transformative Islam.

First, the technical importance of Rational Islam Their Islamic research is carried out in fulfilling the function of setting opinions, eliminating doubts and finally gaining trust about solid Islam. To arrive at this goal, of course a logical tool in the traditional sense, is very important in analyzing the rationality of the Koran to gain knowledge which will later be used as the basis for the testimony of a belief. A trust that is believed to be valid, is expected to orient behavior.

What is sought in Rational Islam is the discovery of fundamental knowledge about Islam (rational Islamic science). To get rational beliefs (rational faith), and subsequently ethically responsible behavior (rational charity). These three things (rational Knowledge, Faith and Charity) are important, to get an Islamic "work" orientation. What is meant by work orientation here is how Islam can be applied in everyday life, without the need for symbolic interpretations let alone complicated mystical interpretations.

In summary, the epistemological foundation of Rational Islam is, the belief that basically that Islam is rational. Meanwhile rationality becomes the ultimate and most decisive entity for the truth of an Islamic proposition. Because Islamic thought here is not an empirical thought, but let's say for the convenience of philosophical theology, rationality is not merely Rational, but a rationality that can be accounted for from an epistemological, or metaphysical

\footnotetext{
20 Ibid

${ }^{21}$ Jurgen Habermas, Knowledge and Human Intrest, (Boston: Bacaan Press, 1995), p.313
} 
perspective (any system of thought can be rational, just look at it from which angle (distinguish Asy-Ariah thinking, which is not bene rational theological thought) .That is why this Islamic Rationalism is "truly Rational", because in this Rationalism inclusive inclusive contained a critical attitude, with great appreciation on the role of reason, and the criticism is seen in the strong pressure to make distinctions, categories, analysis, etc. It is this analytic nature that makes "Rational Islam" strong (Tough Minded) as a Rational theology. a rational Islamic theology, which shows the function of revelation ba gi man, understand human freedom, about the attributes of God, the relationship between justice and God's power, and about God's actions towards humans. From this theological Rational view (on Harun Nasution), they also continue the analysis of the Koran, to see the extent to which the analysis of the Koran, in looking at humans and their life goals as Khalifatullah Fil Ardh (Koran Anthropologist). The main character of Islamic Rationalism is Harun Nasution.

Second, the importance of Islamic civilization, is "practical", to get the meaning of the concrete manifestation of the Koran, therefore, besides the hermenetic analysis of the key concepts of the Koran, they also pay great attention to Islam of the Salaf (al-salaf al-shalih). The method used to understand how "true Islam" is in terms of social philosophy, is called Verstehen (empathy tries to understand how the salaf people live and practice Islam. They, with this method of empathy / phenomelogis, do not look for rational laws, such as Muslims Rational, but want to find the meaning of the process of forming Islam as a historical impetus, which results in an Islamic civilization or Marshell Hodgson's term, Islamicate Culture.

"Islamic Civilization" in this case, especially Nurcholish Madjid, considers that Islamic rationalism, which in the classical Islamic tradition emerged in the Mu'tazilite theology and Al-Kindi to Ibn Rushd's theology, then systematically became the rational theology of Muhammad Abduh. Basically Hellenistic, because that is not an Islamic genuin. Theological thought and Rational philosophy according to Islamic circles This civilization was built from the construction of Greek theories (especially Aristotle), which from an Islamic point of view, is actually quite problematic, because it is too Rational. The weakness of this Islam, according to the circles of 'Islamic Civilization because they lack in providing an equilibrium in religious life, which is practical and direct to the daily appreciation of God. In the language of Religious Philosophy, Harun Rational Islam, is actually a Philosophical Islam, or a theology that is natural (natural theology). Because of this problem, the Islamic Civilization circles are trying to find new alternatives to modern Islamic philosophy, replacing the philosophy of Classical Islam which is very proud of the view of rational Islam. Their starting point is Classical Islamic thought which saved Islam from the attack of total Hellenism, namely the theology of Al Asy-Ariyah, Ibn Taymiyah and Al-Gazali.

It is interesting that their cars build this Islamic philosophy (which, the value claimed is universal) is done by semantic analysis, to see the purpose, meaning and motives of the language or a term Al-Irfan (distinguish Wittgenstein's epistemology). The purpose of this semantic analysis is to see what are actually the moral ideas of the Qur'an, and how far they relate to monotheism.

Third, the interests of Transformist Islam are emancipatory, Mainstream which has always been the basis for interpreting their Qur'an is the Qur'anic vision of transformation because they are motivated by radical social science, so from the beginning they were convinced that there was an empirical and structural process, which had led to an oppression. Since the beginning they have been critical of the notion of Islam which is an Islamic ideology. In this interpretation of Islam modernity is actually identical with the West or Westernization. And the West is synonymous with Capitalism. While capitalism is the parent of the current ideology of imperialism, whether direct or not, in the form of violence or peace 
that has dominated and made the Muslim World and the Third World generally poor and backward from the shackles of structural domination, this is the agenda of transformational Islam.

\section{Conclusion}

The 'Transformative Islam' group developed in many circles whose educational background was not IAIN, but their commitment to Islam was high, or from IAIN, but then appreciated social science in such a way, exceeding its appreciation of traditional Islamic sciences. Most of them are NGOs. In addition they are also colored by the tradition of critical ebiology. Frankfort school and other Neo-Marxists, for example A.Gramsci and the theory of Independence. Their character is very strong in defending the interests that have been made in legitimating social injustice, at the domestic and global level.

Their main concern, first of all, is a social transformation, not a transformation in the sense of "Islamic Civilization", which emphasizes the development of an economically strong Islamic political middle class and commitment to the basic values of Islam, but the transformation of the lower classes. In the word transformation is contained an empowerment of the people to organize themselves in improving human dignity and human dignity. Therefore the moral idea of Islamic justice (which is widely discussed among the "Islamic Civilization") they translate not only positively (and this is the merit of the "Islamic Civilization") but moreover confirmed by reversing it negatively. Even though there is injustice, how should Islam behave?

For the way it works, the term Herbert Marcuso, this negative dialect, their Islamic analyzes enter the wider social world. Specifically, an analysis of capitalism and the role of the state in the processes of social injustice, poverty and underdevelopment (something that is simply ignored or not deeply considered by 'rational Islam' and 'Islamic civilization' circles).

Dengan cara analisis keIslaman ini, jadilah suatu permikiran keIslaman transformatif, yang tekanannya bukan mengusahakan transformasi umat atau masyarakat ke arah kemodernan saja (cita-cita utama dua "Islam" yang lain), tetapi mentransformasikan strukturstruktur masyarakat yang menindas, ke arah struktur yang lebih fungsional dan humanis, untuk perelisasian martabat manusia. Merekapun memikirkan bagaimana agama bisa berperan (setidaknya secara idiologis) dalam mengontrol made of production dalam masyarakat. Untuk itu penyadaran (conscientizing ) akan bentuk-bentuk penguasaan atau dominasi made of production, dan simbol-simbol serta makna yang muncul melalui diskursus dalam istilah al-Faucault oleh sekelompok elit masyarakat (kapitalis), yang lewat struktur sosial yang mereka ciptakan, menjadi bagian penting dari agenda sosial-transformasi Islam ini, khususnya agar masyarakat tertindas dapat memperjuangkan hak martabat mereka. Tokoh utama 'Islam transformatif ini adalah M. Dawam rahardjo dan Adi Sasono.

Perhaps the most obvious obstacles still must be overcome are the obstacles that continue to face the theological / religious reform movement figures of course, the speculative or non-concrete features of their agendas also contribute to the fact that their renewal efforts are overly vulnerable tasks and sensitive to do both emotionally and intellectually. It is true that supporters of this school both openly and vice versa are multiplying in number. But the number of its critics has not diminished. There are even strong indications that in these recent years, the latter group has become increasingly aggressive in expressing their criticism and cynicism about the religious ideas of reformism.

Look at the discourse patterns that take place today. the debate going on between them, between the reformers and their critics, is not intellectually important and does not support practically to bridge the differences. 


\section{References}

A, Giddens. (1991) Modernity and Self-Identity: Self and Society in the Late Modern Age Cambridge: Polity Press,

A, Hafidz Dasuki, et al, (1994) Ensiklopedi Islam, PT. Ichtiar Baru Van Houve, Jakarta.

A, Hanafi. (2001) Pengantar Theologi Islam, Jakarta : PT.Al Husna Zikra.

A'la Al-Maududi. (1977). Abu, The Islamic Law and Constitution, tranalated and edited by Khursyid Ahmad, Lahore Islamic Publication.

Abdullah, Taufik. (1981) "The Sociocultural Scone in Indonesia, dalam Leo Suryadinata, Ced, Trend in Indonesia 11, Singapore, Singapore, University Press.

Arkoun, Muhammad. (1996) Aina huwa al-Fikr al-Islâmy al- Muâshir. Cetakan Kedua. Bairut: Dâr el-Sâqy..

Arkoun, Muhammad, Aina. (1996). Huwa al-fikr al-Islamy al Mu'ashir, Cet.ke dua Bairut Darel Saqy.

Asmuni M, Yusran. (1993) Ilmu Tauhid, Jakarta: Rajawali Pers.

Aziz Dahlan. (1983). Abdul, Pemikiran Muhammadiyah Dalam Bidang Theologi Islam (Teologi Takdir), Jakarta: IAIN Jakarta.

Azra, Azyumardi. (1996 ). "Neo-Sufisme dan Masa Depannya" dalam Muhammad Wahyuni Nafis, Rekonstruksi dan Renungan Relegius Islam (Jakarta: Paramadina).

Azyumardi Azra. (1990). Pergolakan Politik Islam: Dani Fundamentalisme, Módernisme Hingga Post-Modernisme (Jakarta: Paramadina), hlm. 103, Khususnya catatan end not no. 5.

Bahjat, Ahmad. (1990). Allah Fi Al-Aqidah Al-Islamiayah Kairo : Al-Mukhtar Al-Islami.

Baso, Ahmad. (2001) "Neo-Modernisme Islam Versus Post-T radisionalisme Islam", dalam Jurnal T ashwirul Afkar, No. 10, T ahun.

Baso, Ahmad. (2001). "Neo-Modernisme Islam Versus Post-Tradisionalisme Islam", dalam Jurnal Tashwirul Afkar, No. 10, Tahun.

Boullata, Issa J, Dekonstruksi Tradisi, Gelegar Pemikiran Arab Islam

Iryadi, I. (2019). Muslim and Democracy: A Reflection from 2012 Aceh's Gubernatorial Election. Budapest International Research and Critics Institute-Journal (BIRCIJournal). P. 545-555.

Muda, I and Suharyanto, A. (2020). Analysis of life's inter-religious harmony based on the philosophy of Dalihan Na Tolu in Sipirok Sub-district, South Tapanuli Regency, North Sumatera Province. Journal Of Human Behavior In The Social Environment.

Wahid, Abdurrahman. (1984). Nadhatul Ulama dan Islam di Indonesia di Dewasa ini, Jakarta: Prisma, LP3ES, April,.

Wahid, Abdurrahman, Pesantren sebagai Subkuktur. Dalam at Dawan Raharjo (Ed), Pesantren dan Pembaharuan, Jakarta: LP3ES.

Wehr, Hans. (1974). A Dictionary of Modern Written Arabic, (London: Macdonald \& Evan Ltd.,).

Wijaya, Aksin. (2004) Menggugat Otensitas Wahyu T uhan; Kritik Atas Nalar Tafsir Gender, Yogyakarta: Safiria Insania Press.

WW, Rostow. (1977). The Stoges of Economic Growth, Second Edition Cambridge Univesity Press.

Zayd, Nasr Hamid Abu.( 1990) Naqd al-Khitab al-Dini, Qahirah: Maktabah Madbuli.

Zuhri, Amat. (2011). Warna-warni Teologi Islam (Ilmu Kalam) cet. ke 5. Pekalongan: STAIN Press. 